\title{
Effects of Reactive Nitrogen Scavengers on NK-Cell-Mediated Killing of K562 Cells
}

\author{
Yili Zeng, ${ }^{1}$ Qinmiao Huang, ${ }^{1}$ Meizhu Zheng, ${ }^{2}$ Jianxin Guo, ${ }^{1}$ and Jingxin Pan ${ }^{1}$ \\ ${ }^{1}$ Department of Hematology, The Second Affiliated Hospital of Fujian Medical University, Fujian, Quanzhou 362000, China \\ ${ }^{2}$ Department of Medicine, Shishi hospital, Fujian, Quanzhou 362000, China
}

Correspondence should be addressed to Jingxin Pan, onlyonepjx@yahoo.com.cn

Received 28 October 2011; Accepted 27 December 2011

Academic Editor: Su S. Chen

Copyright ( 2012 Yili Zeng et al. This is an open access article distributed under the Creative Commons Attribution License, which permits unrestricted use, distribution, and reproduction in any medium, provided the original work is properly cited.

\begin{abstract}
This study explored the effects of reactive nitrogen metabolites (RNMS) on natural-killer- (NK-) cell-mediated killing of K562 cells and the influence of RNM scavengers, such as tiopronin (TIP), glutamylcysteinylglycine (GSH), and histamine dihydrochloride (DHT), on reversing the suppressing effect of RNM. We administered exogenous and endogenous RNM in the NK + K562 culture system and then added RNM scavengers. The concentrations of RNM, TNF- $\beta$ and IFN- $\gamma$, and NK-cell cytotoxicity (NCC) and the percentage of living NK cells were then examined. We found that both exogenous and endogenous RNM caused the KIR to decrease $(P<0.01)$; however, RNM scavengers such as TIP and GSH rescued this phenomenon dose dependently. In conclusion, our data suggests that RNM scavengers such as TIP and GSH enhance the antineoplasmic activity of NK cells.
\end{abstract}

\section{Introduction}

There is a great number of monocytes/macrophages (MO) and NK cells within and outside malignant tumors. Compared with other sections of body, the function of NK cells in a tumor and its ambient tissue is remarkably decreased [1]. Current antitumor immunotherapies mainly use adoptive immunotherapy (AIT), which involves cells such as cytotoxic T lymphocytes (CTLS), lymphokine-activated killer cells (LAK cells), tumor-infiltrating lymphocytes (TILS), multicytokine-induced killer cells (CIK cells), donor lymphocyte infusions (DLIS), antineoplastic lymphocyte clones, and haplotype lymphocyte infusions. T cells and NK cells are the major effective cells, whereas interleukin-2 (IL-2) is the main activator of T/NK cells. However, most studies using IL-2 alone to treat leukemia in vivo have shown low efficacy, with only a few patients achieving remission. The main reason for this result is that certain monocytes/macrophages (MO) that can inhibit the antitumor activity of lymphocytes were quantitatively shown to exist in and around the tumor tissue. MO participate in tumor-induced immune suppression by secreting cytokines, particularly reactive oxygen metabolites (ROMS) and reactive nitrogen metabolites (RNMS) [2]. Studies have confirmed that the ROM yielded by $\mathrm{MO}$ inhibit the antitumor activity of lymphocytes when respiratory bursts occur. DHT, TIP, and GSH can reverse the inhibition of the antitumor activity of NK cells by ROM $[3,4]$. In our previous studies, we also demonstrated that TIP and GSH were superior to DHT in reversing the suppression of the antitumor activity of T/NK cells by ROM [5]. When respiratory bursts occur, $\mathrm{MO}$ yield not only ROM but also RNM, which include nitrogen monoxide (NO), $\mathrm{NO}_{2}$, $\mathrm{NO}_{2}{ }^{-}, \mathrm{NO}_{3}{ }^{-}$, and peroxynitrite $\left(\mathrm{ONOO}^{-}\right)$. The function of RNM is similar to that of ROM; however, RNM also have nitrogenation activity. Peroxynitrite $\left(\mathrm{ONOO}^{-}\right)$, once acidified, immediately converts to peroxy-nitrous acid in the excited state, which has a stronger oxidizing activity and simultaneously yields both nitrogen dioxide $\left(\mathrm{NO}_{2}\right)$ and $\mathrm{OH}$ analogs. These substances are more toxic than ROM [6]. Kono et al. [7] speculated that, in cancer-bearing animals, reactive nitrogen species induce the downregulation of $\mathrm{CD}^{+}$, which is an important signal transduction molecule in $\mathrm{T} / \mathrm{NK}$ cells. Thus, the antitumor immunosuppression caused by RNM should not be neglected. The immunotolerance to tumors induced by RNM may be similar to or stronger than that of ROM. In our previous studies, we had demonstrated that ROM produced by $\mathrm{MO}$ result in tumor immunosuppression [8]. However, studies examining 
whether RNM causes antitumor immunosuppression have not yet been reported. This research investigates the effects of the exogenous and endogenous RNM on NK-cell-mediated killing of K562 cells and the influence of RNM scavengers such as TIP, GSH and DHT on reversing the suppressing effect of RNM.

\section{Materials and Methods}

2.1. Materials. The K562 cell line was provided by the Union Hospital of Fujian Province. Fresh, enriching leukocytes from healthy patients were obtained from the Quanzhou City Blood Center. The reagents and their manufacturers were as follows: NK Cell Negative Isolation Kit, Dynal; MTT, Trypan Blue, Propidium Iodide, Sigma; CFSE, Dojindo (Japan) interleukin-2, Double Heron (Beijing); phytohemagglutinin, Yihua (Shanghai); histamine dihydrochloride, Sigma; tiopronin, Henan Xinyi Medicine Industry, Ltd.; hydroxy radical detection kit and nitrogen monoxide detection kit, Jiancheng (Nanjing); human IFN- $\gamma$ ELISA Kit, Xinbosheng (Guangzhou); TNF- $\beta$ ELISA Kit, Boster (Wuhan).

2.2. Isolation of Mononuclear Cells Rich in NK Cells (E) [9]. After PBMc were isolated using density gradient centrifugation, they were incubated with the immunomagnetic bead of the NK Cell Negative Isolation Kit at a low temperature. Then, the NK cells were isolated by the magnetic sorption method. Flow cytometry (FCM) was applied to detect the cells marked with CD3-FITC/CD56+16-PE. There were $85 \%$ of $\mathrm{CD}-/ \mathrm{CD} 56+/ \mathrm{CD} 16+$ cells, and more than $95 \%$ of cells were shown to be alive via the trypan blue exclusion assay.

2.3. Isolation of Mononuclear Cells Rich in Monocytes (MO). After isolating by the density gradient, the PBMc were cultured adherently to isolate the monocytes. Then, they were identified by a nonspecific carboxylesterase staining method. The MO constituted of $76.3 \%$ of the total cells, and more than $95 \%$ of cells were shown to be alive via the trypan blue exclusion assay.

2.4. Viable NK-Cell Counting (CFSE-PI Double Staining Method). CFSE labeling: a $1 \mu \mathrm{m}$ solution that contained $5 \mathrm{mM}$ CFSE was diluted with $1 \mathrm{~mL}$ PBS containing $10 \%$ FCS, followed by incubation with $1 \mathrm{~mL}$ of the cells at $37^{\circ} \mathrm{C}$ for $5-$ 10 minutes. PI staining: the cells were stained with PI for 10 minutes at a concentration of $2.5 \mu \mathrm{g} / \mathrm{mL}$. Stained cells were analyzed using COULTER flow cytometry. The fluorescence intensity of CFSE and PI was detected by the FL1 and FL3 channels, respectively. The NK cells were firstly gated as CFSE-positive cells. The CFSE and PI double-positive cells (upper-right quadrant) were dead cells, and viable NK cells were shown in the upper-left quadrant. The percentage of viable NK cells was the same as the percentage of plots in upper-left quadrant.

2.5. ROM Assay. ROM production was assayed by spectral luminosity chromatometry following the instructions on the hydroxy radical detection kit (Jiancheng, Nanjing).
2.6. RNM Assay (Nitrate Reductase Method). RNM production was assayed indirectly using chromatometry following the instructions of the nitric oxide detection kit (Jiancheng, Nanjing).

2.7. NK-Cell Cytotoxicity (NCC). NCC was assayed by the MTT method.

2.8. TNF- $\beta$ and IFN- $\gamma$ Assay. The IFN- $\gamma$ and TNF- $\beta$ levels were assayed to indirectly reflect the activity of NK cells by double antibody sandwich enzyme-labeled immunosorbent assay, according to the manufacturers' instructions. The concentration gradients of the standard preparations and their corresponding optical density results were imported into the program SPSS 13.0 to generate standard calibration equations for conversion of OD values to concentrations. These calibration equations were used to determine the concentrations of IFN- $\gamma$ and TNF- $\beta$.

2.8.1. The Effect of $\mathrm{ONOO}^{-}$on the Activity of NK Cells. NK cells (E) and K562 cells (T) were cultured in 96-well plates at a ratio $(\mathrm{E}: \mathrm{T})$ of $10: 1$. The cells were cocultured at $37^{\circ} \mathrm{C}$ in an atmosphere of $5 \%$ carbon dioxide $\left(\mathrm{CO}_{2}\right)$ and saturated humidity. RNM production was measured 6 hours later, and the TNF- $\beta$ and IFN- $\gamma$ levels were determined 24 hours later. In addition, the number of viable NK cells was measured by FCM 6 and 24 hours later. The equation for NCC was $\mathrm{NCC}=\left[1-\left(\mathrm{OD}_{\mathrm{E} / \mathrm{T}}-\mathrm{OD}_{\mathrm{E}}\right) / \mathrm{OD}_{\mathrm{T}}\right] \times 100 \%$ [10]. All measurements were carried out in triplicate. NK cells, K562 cells, and NK cells + K562 cells were used as blank groups, and DMEM containing 10\% FBS was used as the holo-blank sample. The production of RNM and the extent of the inhibition of NK on K562 cells were measured at the indicated time points, and the data were analyzed to evaluate the relationship between RNM levels and the activity of NK cells.

2.8.2. The Effect of Endogenous RNM on the Activity of NK Cell. IL-2 $(150 \mathrm{U} / \mathrm{mL})$ and PHA $(60 \mathrm{~g} / \mathrm{mL})$ were administered to cocultures of $\mathrm{NK}$ cells and $\mathrm{MO}$ at a ratio $(\mathrm{E}: \mathrm{MO})$ of $10: 2$. After 24 hours of coculture, K562 cells were added at an $\mathrm{E}: \mathrm{T}$ ratio of $10: 1$. RNM production was measured 6 hours later, while TNF- $\beta$ and IFN- $\gamma$ levels and KIR were measured 24 hours later. Each group was tested three times. Blank groups containing IL-2/PHA were the same as those described in paragraph 2.3 .

2.8.3. The Effect of Different Dosages of RNM Scavengers on the Activity of NK Cells. In the $\mathrm{NK}+\mathrm{MO}(\mathrm{E}: \mathrm{MO}=10: 2)$ mixed-cell culture system, IL-2 $(150 \mathrm{U} / \mathrm{mL})$ and PHA $(60 \mathrm{ug} / \mathrm{mL})$ were first administered. After 24 hours of coculture, K562 cells were added at a ratio of $\mathrm{E}: \mathrm{T}=10: 1$. At the same time, different concentrations of DHT ( $10 \mathrm{umol} / \mathrm{L}$, $20 \mathrm{umol} / \mathrm{L}, 50 \mathrm{umol} / \mathrm{L})$ and TIP $(125 \mathrm{~mol} / \mathrm{L}, 50 \mathrm{~mol} / \mathrm{L}$, $100 \mathrm{~mol} / \mathrm{L}, \quad 250 \mathrm{~mol} / \mathrm{L})$ and $\mathrm{GSH}(25 \mathrm{~mol} / \mathrm{L}, \quad 50 \mathrm{~mol} / \mathrm{L}$, $100 \mathrm{~mol} / \mathrm{L}, 250 \mathrm{~mol} / \mathrm{L}$ ) were added to separate wells. The production of RNM was measured after another 6 hours, and the levels of TNF- $\beta$ and IFN- $\gamma$ were measured after 48 hours. In addition, MTT was used to measure KIR. All 
TABLE 1: The effect of $\mathrm{ONOO}^{-}$on the activity of NK cell.

\begin{tabular}{|c|c|c|c|c|c|c|}
\hline Groups & $\mathrm{NO}(6 \mathrm{~h})(\mu \mathrm{mol} / \mathrm{mL})$ & NK $(6 h) \%$ & NK $(24 \mathrm{~h}) \%$ & TNF- $\beta$ ( $24 \mathrm{~h}) \mathrm{pg} / \mathrm{mL}$ & IFN- $\gamma(24 \mathrm{~h}) \mathrm{pg} / \mathrm{mL}$ & NCC $(24 \mathrm{~h}) \%$ \\
\hline Control & $11.29 \pm 5.02$ & & & $6.63 \pm 6.42$ & $10.80 \pm 5.05$ & \\
\hline $\mathrm{E}$ & $52.90 \pm 8.61$ & $89.87 \pm 1.93$ & $87.37 \pm 2.11$ & $183.08 \pm 7.45$ & $136.32 \pm 6.5$ & \\
\hline $\mathrm{T}$ & $25.68 \pm 5.96$ & & & $11.96 \pm 5.89$ & $12.02 \pm 95$ & \\
\hline $\mathrm{E}+\mathrm{T}$ & $95.36 \pm 6.45$ & $90.57 \pm 2.52$ & $92.16 \pm 2.53$ & $198.64 \pm 7.33$ & $146.43 \pm 6.49$ & $66.32 \pm 4.34$ \\
\hline $\mathrm{E}+\mathrm{ONOO}^{-}$ & $264.85 \pm 9.16^{\#}$ & $80.41 \pm 2.52^{\#}$ & $81.05 \pm 1.58^{\#}$ & $86.07 \pm 7.51^{\#}$ & $58.46 \pm 6.12^{\#}$ & \\
\hline $\mathrm{T}+\mathrm{ONOO}^{-}$ & $228.35 \pm 8.45^{*}$ & & & $11.07 \pm 5.52$ & $12.10 \pm 5.02$ & \\
\hline $\mathrm{E}+\mathrm{T}+\mathrm{ONOO}^{-}$ & $261.03 \pm 6.57^{\Delta}$ & $80.97 \pm 1.677^{\Delta}$ & $73.87 \pm 1.021^{\Delta}$ & $91.68 \pm 6.00^{\Delta}$ & $58.47 \pm 6.99^{\triangle}$ & $43.84 \pm 3.42^{\triangle}$ \\
\hline
\end{tabular}

$n=3$; $\mathrm{T}$ is K562 cells, $\mathrm{E}$ is mononuclear enriching NK cells $\mathrm{E} / \mathrm{T}=10 / 1{ }^{\#} P<0.05$, comparison between group $\mathrm{E}+\mathrm{ONOO}^{-}$and group $\mathrm{E} ;{ }^{*} P<0.05$, comparison between group $\mathrm{T}+\mathrm{ONOO}^{-}$and group $\mathrm{T} ;{ }^{\triangle} \mathrm{P}<0.05$ comparison between group $\mathrm{E}+\mathrm{T}+\mathrm{ONOO}^{-}$and group $\mathrm{E}+\mathrm{T}$.

the experiments for each group were repeated three times. Meanwhile, IL-2/PHA + NK + K562 cultures (Control 1) and $\mathrm{IL}-2 / \mathrm{PHA}+\mathrm{NK}+\mathrm{K} 562+\mathrm{MO}$ cultures (Control 2) were used as the blank control groups. The levels of RNM, TNF- $\beta$ and IFN- $\gamma$, and KIR without DHT, TIP, and GSH were compared with the corresponding values after addition of the different doses of drugs. This allowed us to determine which dose of DHT and TIP and GSH could reverse the inhibitory effect of $\mathrm{MO}$ on the antitumor activity of NK cells effectively.

2.8.4. The Effect of Different Combinations of RNM Scavengers on the Activity of NK Cells. In the $\mathrm{NK}+\mathrm{MO}(\mathrm{E}: \mathrm{MO}=$ $10: 2)$ mixed-cell culture system, IL-2 $(150 \mathrm{U} / \mathrm{mL})$ and PHA $(60 \mathrm{ug} / \mathrm{mL})$ were administered first. After 24 hours of coculture, K562 cells were added at a ratio of E:T = $10: 1$, and at the same time, different combinations of DHT $(20 \mu \mathrm{mol} / \mathrm{L})$, TIP $(50 \mathrm{~mol} / \mathrm{L}, 100 \mathrm{~mol} / \mathrm{L})$, and GSH $(50 \mathrm{~mol} / \mathrm{L})$ were added to each well. The production of RNM was measured after another 6 hours, and the levels of TNF- $\beta$ and IFN- $\gamma$ were measured after 48 hours. In addition, MTT was used to measure KIR. All experiments were repeated three times. Meanwhile, IL-2/PHA + NK + K562 cultures and IL-2/PHA $+\mathrm{NK}+\mathrm{K} 562+\mathrm{MO}$ cultures were used as the blank control groups. The levels of RNM, TNF- $\beta$ and IFN$\gamma$, and NCC with DHT, TIP, and GSH were compared with the corresponding values after the addition of the different combinations of RNM scavengers. This allowed us to know which combination of DHT, TIP, and GSH could reverse the inhibitory effect of MO on the antitumor activity of NK cells effectively.

2.9. Statistical Analysis. SPSS 13.0 statistical software was used to analyze the results. The measurements were reported as $x \pm \mathrm{SD}$. The LSD $t$-test was taken when the mean squares were regular, while the Dunnett $T 3$ test was used to measure the heterogeneity of variance during the multiple comparisons of the means of all groups. $P<0.05$ was taken as the level of significance.

\section{Results}

3.1. The Effect of $\mathrm{ONOO}^{-}$on the Activity of NK Cells. After exogenous $\mathrm{ONOO}^{-}$was administered in the coculture system of NK and K562 cells, the RNM production increased
$(P<0.05)$, whereas the concentration of TNF- $\gamma$ and IFN$\beta$ and the NCC was significantly decreased $(P<0.05)$. The percentage of living NK cells was also decreased by the FCM at the 6th and the 24th hours. These data are shown in Table 1.

\subsection{The Effect of RNM Scavenger on NK-Cell Cytotoxicity} Caused by $\mathrm{ONOO}^{-}$. To explore the effect of RNM scavengers on NK-cell cytotoxicity caused by $\mathrm{ONOO}^{-}$, we used three RNM scavengers. As shown in Table 2, we found that the production of RNM in the systems of NK and K562 cells decreased significantly after administration of TIP and GSH $(P<0.05)$, while the percentage of living NK cells and the concentration of TNF- $\gamma$ and IFN- $\beta$ and NCC were significantly increased $(P<0.05)$.

\subsection{The Effect of Endogenous RNM on the Activity of NK Cells.} We know that exogenous RNM reduces the activity of NK cells. Furthermore, we investigated the effect of endogenous RNM on the activity of NK cells. The results are shown in Table 3, when the number of NK cells was fixed. After activation by IL-2/PHA, the levels of IFN- $\gamma$ and TNF- $\beta$ were significantly higher than at the same $\mathrm{E}$ : $\mathrm{T}$ ratios in the absence of IL-2/PHA $(P<0.05)$. With a further addition of MO, the level of IFN- $\gamma$ and TNF- $\beta$ did not increase $(P>$ 0.05 ), while the production of TNF- $\beta$ increased to a small extent over the level prior to the addition of $\mathrm{MO}$, and the NCC was lower.

3.4. The Effect of RNM Scavenger on NK-Cell-Mediated Killing of K562 Cells. As shown in Table 4, the addition of TIP and GSH reduced the production of RNM and ROM and increased the production of TNF- $\gamma$ and IFN- $\beta$ and NCC significantly $(P<0.05)$; however, DHT incubation did not reduce the production of RNM effectively $(P>0.05)$.

3.5. The Effect of Different Dosages of RNM Scavengers on the Activity of NK Cells. To investigate whether different dosages of RNM scavengers affect the activity of NK cells, we selected different combinations, as shown in Figure 1. According to Figure 1, with an increase of the dosage, the groups treated with TIP and GSH decreased the production of RNM and increased the levels of TNF- $\gamma$, IFN- $\beta$ and NCC significantly 
TABLE 2: The effect of RNM scavengers on NK-cell cytotoxicity of $\mathrm{ONOO}^{-}$.

\begin{tabular}{|c|c|c|c|c|c|c|}
\hline Groups & $\mathrm{NO}(6 \mathrm{~h})(\mu \mathrm{mol} / \mathrm{mL})$ & NK $(6 h) \%$ & NK $(24 \mathrm{~h}) \%$ & TNF- $\beta(24 \mathrm{~h}) \mathrm{pg} / \mathrm{mL}$ & IFN- $\gamma(24 \mathrm{~h}) \mathrm{pg} / \mathrm{mL}$ & $\operatorname{NCC}(24 \mathrm{~h}) \%$ \\
\hline $\mathrm{E}+\mathrm{T}$ & $95.36 \pm 6.45$ & $90.57 \pm 2.52$ & $93.17 \pm 2.57$ & $198.64 \pm 7.33$ & $146.43 \pm 6.49$ & $67.47 \pm 2.64$ \\
\hline $\mathrm{E}+\mathrm{T}+\mathrm{ONOO}^{-}$ & $261.03 \pm 6.57$ & $80.97 \pm 1.68$ & $71.87 \pm 1.02$ & $91.68 \pm 6.00$ & $58.47 \pm 70$ & $43.44 \pm 2.87$ \\
\hline $\mathrm{E}+\mathrm{T}+\mathrm{DHC}+\mathrm{ONOO}^{-}$ & $255.32 \pm 11.93$ & $82.27 \pm 1.38$ & $73.60 \pm 2.76$ & $118.73 \pm 5.56^{*}$ & $70.40 \pm 7.15^{*}$ & $45.26 \pm 3.31$ \\
\hline $\begin{array}{l}\mathrm{E}+\mathrm{T}+\mathrm{TIP}+ \\
\mathrm{ONOO}^{-}\end{array}$ & $179.65 \pm 7.00^{*}$ & $90.07 \pm 1.23^{*}$ & $91.13 \pm 3.67^{*}$ & $131.03 \pm 5.46^{*}$ & $76.80 \pm 4.91^{*}$ & $61.58 \pm 1.89^{*}$ \\
\hline $\begin{array}{l}\mathrm{E}+\mathrm{T}+\mathrm{GSH}+ \\
\mathrm{ONOO}^{-}\end{array}$ & $185.69 \pm 5.02^{*}$ & $89.87+0.35^{*}$ & $88.03 \pm 1.46^{*}$ & $128.70 \pm 4.53^{*}$ & $75.12 \pm 6.45^{*}$ & $60.68 \pm 2.07^{*}$ \\
\hline
\end{tabular}

$n=3 ; 2 . \mathrm{ONOO}^{-} 200 \mathrm{umol} / \mathrm{L} ; \mathrm{DHC} 20 \mathrm{umol} / \mathrm{L}$, TIP $50 \mathrm{umol} / \mathrm{L}, \mathrm{GSH} 50 \mathrm{umol} / \mathrm{L} ; \mathrm{T}$ is $\mathrm{K} 562$ cells, $\mathrm{E}$ is mononuclear enriching NK cells $\mathrm{E} / \mathrm{T}=10 / 1 ; * P<0.05$, compared with $\mathrm{E}+\mathrm{T}+\mathrm{ONOO}^{-}$.

TABle 3: The effect of endogenous RNM on the activity of NK cells.

\begin{tabular}{|c|c|c|c|c|}
\hline Groups & $\mathrm{NO}(6 \mathrm{~h})(\mu \mathrm{mol} / \mathrm{mL})$ & TNF- $\beta(24 \mathrm{~h}) \mathrm{pg} / \mathrm{mL}$ & IFN- $\gamma(24 \mathrm{~h}) \mathrm{pg} / \mathrm{mL}$ & NCC $(24 \mathrm{~h}) \%$ \\
\hline Control & $11.68 \pm 6.62$ & $11.08 \pm 5.46$ & $11.65 \pm 5.05$ & \\
\hline $\mathrm{T}+\mathrm{IL}-2 / \mathrm{PHA}$ & $22.29 \pm 5.66$ & $20.64 \pm 5.57$ & $13.18 \pm 5.86$ & \\
\hline $\mathrm{MO}+\mathrm{IL}-2 / \mathrm{PHA}$ & $114.37 \pm 7.40$ & $40.64+7.59$ & $47.76 \pm 6.57$ & \\
\hline $\mathrm{E}+\mathrm{IL}-2 / \mathrm{PHA}$ & $62.64 \pm 7.00$ & $361.62 \pm 12.27$ & $284.74 \pm 7.49$ & \\
\hline $\mathrm{E}+\mathrm{MO}+\mathrm{IL}-2 / \mathrm{PHA}$ & $119.62 \pm 11.18$ & $114.09 \pm 7.46$ & $76.77 \pm 4.99$ & \\
\hline $\mathrm{MO}+\mathrm{T}+\mathrm{IL}-2 / \mathrm{PHA}$ & $115.26 \pm 6.47$ & $33.31 \pm 6.34$ & $46.46 \pm 6.97$ & \\
\hline $\mathrm{E}+\mathrm{T}+\mathrm{IL}-2 / \mathrm{PHA}$ & $79.63 \pm 7.04$ & $371.99 \pm 12.79$ & $275.08 \pm 9.61$ & $91.77 \pm 3.62$ \\
\hline $\mathrm{E}+\mathrm{T}+\mathrm{MO}+\mathrm{IL}-2 / \mathrm{PHA}$ & $189.35 \pm 6.51^{*}$ & $110.91 \pm 10.01^{*}$ & $74.74 \pm 10.15^{*}$ & $60.39 \pm 5.39^{*}$ \\
\hline
\end{tabular}

$n=3$; $\mathrm{ONOO}^{-} 200 \mathrm{umol} / \mathrm{L} ; \mathrm{DHT} 20 \mathrm{umol} / \mathrm{L}$, TIP $50 \mathrm{umol} / \mathrm{L}, \mathrm{GSH} 50 \mathrm{umol} / \mathrm{L} ; \mathrm{T}$ is K562 cells, $\mathrm{E}$ is mononuclear enriching NK cells $\mathrm{E} / \mathrm{T}=10 / 1 ; * P<0.05$, comparison between group NK + MO + K562 + IL-2 and group NK + K562 + IL-2.

TABLE 4: The effect of RNM scavengers on NK-cell-mediated killing of K562 cells.

\begin{tabular}{|c|c|c|c|c|c|}
\hline Groups & $\mathrm{OH}(6 \mathrm{~h})(\mathrm{U} / \mathrm{mL})$ & $\mathrm{NO}(6 \mathrm{~h})(\mu \mathrm{mol} / \mathrm{mL})$ & TNF- $\beta(24 \mathrm{~h}) \mathrm{pg} / \mathrm{mL}$ & IFN- $\gamma(24 \mathrm{~h}) \mathrm{pg} / \mathrm{mL}$ & NCC\% \\
\hline $\mathrm{IL}-2 / \mathrm{PHA}+\mathrm{E}+\mathrm{T}$ & $74.41 \pm 3.05$ & $82.10 \pm 6.60$ & $381.47 \pm 10.64$ & $277.14 \pm 10.61$ & $90.64 \pm 3.06$ \\
\hline $\mathrm{IL}-2 / \mathrm{PHA}+\mathrm{E}+\mathrm{T}+\mathrm{MO}$ & $256.08 \pm 8.52$ & $193.65 \pm 5.95$ & $114.39 \pm 7.45$ & $76.81 \pm 9.50$ & $61.29 \pm 2.22$ \\
\hline $\mathrm{IL}-2 / \mathrm{PHA}+\mathrm{E}+\mathrm{T}+\mathrm{MO}+\mathrm{DHC}$ & $101.37 \pm 5.56^{*}$ & $188.92 \pm 5.00$ & $134.10 \pm 6.68^{*}$ & $107.89 \pm 6.55^{*}$ & $72.20 \pm 4.10^{*}$ \\
\hline $\mathrm{IL}-2 / \mathrm{PHA}+\mathrm{E}+\mathrm{T}+\mathrm{MO}+\mathrm{TIP}$ & $107.02 \pm 6.39^{*}$ & $91.32 \pm 6.81^{*}$ & $185.00 \pm 4.51^{*}$ & $146.71 \pm 6.96^{*}$ & $84.31 \pm 4.56^{*}$ \\
\hline $\mathrm{IL}-2 / \mathrm{PHA}+\mathrm{E}+\mathrm{T}+\mathrm{MO}+\mathrm{GSH}$ & $108.69 \pm 6.05^{*}$ & $84.66 \pm 5.99^{*}$ & $181.91 \pm 5.92^{*}$ & $144.11 \pm 6.03^{*}$ & $81.65 \pm 3.09^{*}$ \\
\hline
\end{tabular}

$n=3 ; \mathrm{ONOO}^{-} 200 \mathrm{umol} / \mathrm{L}$; DHT $20 \mathrm{umol} / \mathrm{L}$, TIP $50 \mathrm{umol} / \mathrm{L}$, GSH $50 \mathrm{umol} / \mathrm{L} ; \mathrm{T}$ is $\mathrm{K} 562$ cells, $\mathrm{E}$ is mononuclear enriching NK cells E/T $=10 / 1 ; * P<0.05$, compared with IL-2/PHA + NK + K562 + MO.

$(P<0.05)$. However, each group of DHT could not eliminate RNM $(P>0.05)$.

3.6. The Effect of Different Combinations of RNM Scavengers on the Activity of NK Cells. To investigate whether different combinations of RNM scavengers affect the activity of NK cells, we selected different combinations, as shown in Figure 2. According to the result of Figure 2, we found that different combinations of RNM scavengers did not enhance the antineoplasmic activity of NK cells.

\section{Discussion}

$\mathrm{ONOO}^{-}$is generated by the $\mathrm{NO}$ and $\mathrm{O}_{2}{ }^{-}$reaction, which can be produced by many cells in our body. Under normal conditions, $\mathrm{ONOO}^{-}$is believed to have a primarily physiological function. However, under pathological conditions, the oxidation and injury role is activated for the increased $\mathrm{ONOO}^{-}$stimulation by inflammatory factor [11]. By detecting the expression of RNM-induced genes, Nittler et al. [12] discovered that RNMS take part in the metabolic process of many types of cells, including T/NK cells in the following ways: (1) by oxidizing and nitrifying DNA residues and deaminating them to induce DNA damage and interfere with DNA repair; (2) by modifying proteins in the electron transfer chain to inhibit cell respiration, promoting the reduction of coenzyme Q10 to increase the production of active oxygen and reducing the proton current rate through the mitochondria to reduce the ATP content of the cell; (3) by mediating the nitrogenation and nitrosylation of proteins and interfering with their correct folding and degradation, thereby influencing cellular activity. Our research showed that the percentage of live NK cells decreased after the addition of synthetic $\mathrm{ONOO}^{-}$into the culture system of $\mathrm{NK}$ 


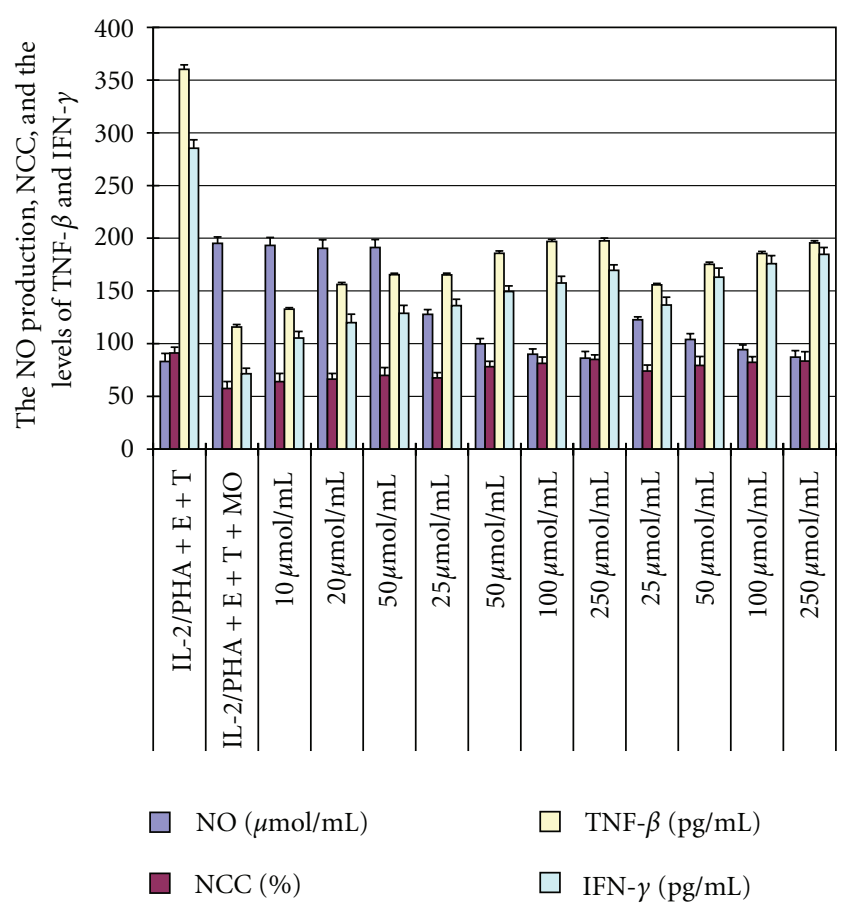

Figure 1: The effect of different dosages of RNM scavengers on the activity of NK cells. With an increase of the dosage, the groups treated with TIP and GSH decreased the production of RNM and increased the levels of TNF- $\gamma$, IFN- $\beta$ and NCC significantly $(P<$ $0.05)$. However, each group of DHT could not eliminate RNM $(P>0.05)$.

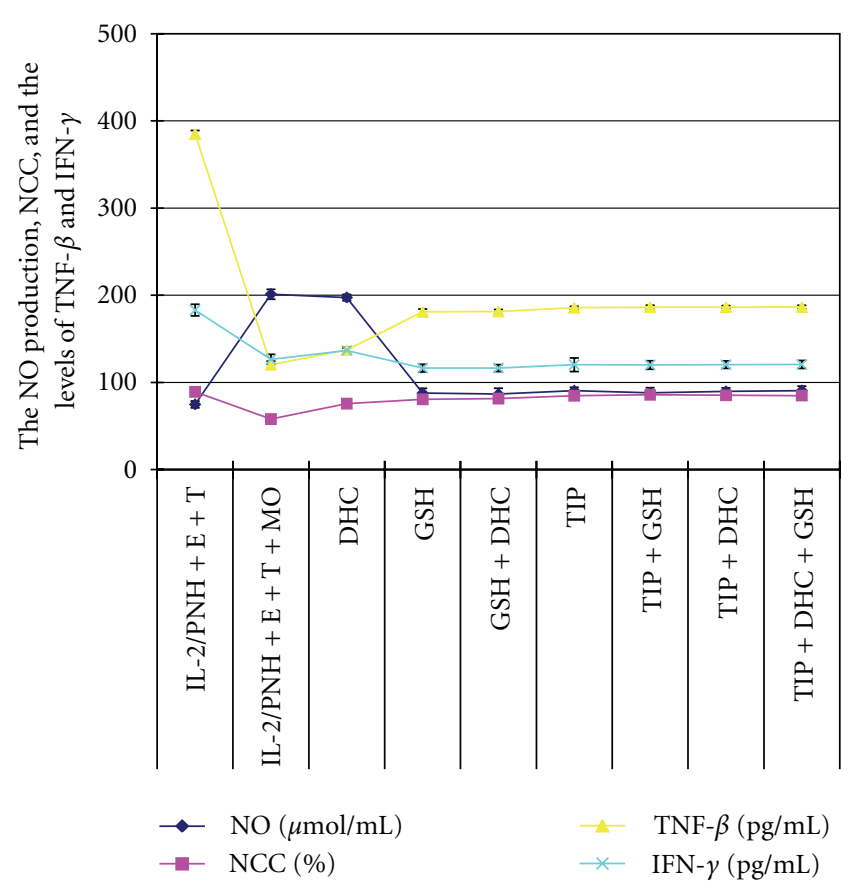

FIGURE 2: The effect of different combinations of RNM scavengers on the activity of NK cells. Different combinations of RNM scavengers did not enhance the antineoplasmic activity of NK cells. and K562 cells, which indicated that the $\mathrm{ONOO}^{-}$can kill NK cells directly. Not only did the lymphokines TNF- $\beta$, IFN$\gamma$ in NK cells decrease significantly, but KIR also decreased dramatically $(P<0.01)$ (Table 1$)$. All the results indicated that exogenous $\mathrm{ONOO}^{-}$had a cell-killing effect on NK cells and inhibited the anti-K562 cells function of NK cells.

The mononuclear phagocyte, which protects the body from pathogenic factors, is an important component of acute and chronic inflammatory reactions. Once phagocytosed foreign bodies are recognized, the phagocyte will have a respiratory burst, which is manifested by an increase in oxygen consumption, enhanced metabolic activity of the pentose phosphate pathway, and the generation of nitrogen and oxygen free radicals, among which the NO can transfer the activating signal from the cytoplasm to endometaphase through the cell signaling pathway and induce the expression of related genes to activate the inflammatory response. This type of oxidizing bactericide is nonspecific, and normal tissues around mononuclear macrophages could also be injured [13]. In this study, IL-2 and PHA were added into the NK $+\mathrm{K} 562+\mathrm{MO}$ culture system, resulting in significant enhancement of RNM, while the NCC decreased from $91.77 \%$ to $60.39 \%(P<0.01)$. Cytokine TNF- $\beta$ IFN- $\gamma$ also decreased after the addition of IL-2/PHA (Table 3 ). These results suggested that RNM produced by the MO cell respiratory burst inhibits NK-cell activity. This result is consistent with that of decreased NK activity and lower NCC induced by addition of exogenous $\mathrm{ONOO}^{-}$. It has been shown that a large number of MO cells can be detected in and around tumors [14]. This study also showed that IL-2 activates T/NK cells in vivo and also induces MO cells to produce a large amount of RNMS. Such a nonspecific killing effect inhibits the activity of T/NK cells, which may explain the low efficiency of adoptive tumor immunotherapy when using the T/NK cell as an effector cell and IL-2 as an activator.

A central goal of tumor therapy is strengthening the immune system in order to eliminate the microresidue of the tumor. Thoren et al. had shown when using IL-2 for treatment that histamine is an ideal immunomodulator that can counter ROM inhibition of the antitumor activity of NK cells through the $\mathrm{H} 2$ receptor [15]. In our previous studies, we also demonstrated that tiopronin was superior to DHT in reversing the suppression by ROM of the antitumor activity of T/NK cells. In this study, TIP and GSH were chosen as scavengers of RNM and were compared with DHT. By adding exogenous $\mathrm{ONOO}^{-}$, TIP, GSH, and DHT into the coculture of NK cells and K562 cells, as shown in Table 2, both tiopronin and glutathione remove RNM directly, which protects $\mathrm{NK}$ cells and reverses $\mathrm{ONOO}^{-}$inhibition of NK-cell activity. However, in the DHT group, no change was found in the RNM and NCC, suggesting that $\mathrm{ONOO}^{-}$cannot be cleared by DHT directly. Table 4 shows the effects of the three kinds of scavengers in removing endogenous RNM generated by $\mathrm{MO}$ cells, which are similar to the effect on exogenous $\mathrm{ONOO}^{-}$. Tiopronin and glutathione can significantly reduce the RNM $(P<0.05)$, while DHT has no effect on RNM production $(P>0.05)$. All three drugs can reduce the ROM output, increase the production of TNF- $\beta$ and IFN- $\gamma$, and enhance the rate of inhibition of K562 cells $(P<0.05)$. 
GSH is tripeptide that is composed of $\gamma$-glutamic acid, and cysteine, and glycine, with a molecular structure that contains a nonprotein thiol, which can be catalyzed by itself or by glutathione transferase system (GST-S), regulating intracellular oxidation-reduction systems and reducing the content of RNM and ROM to play its pharmacological role. With the self-contained free $\mathrm{SH}$, the tiopronin cannot only drive reversible synthesis of disulfide compounds with RNM and $\mathrm{ROM}$, but it can also activate $\mathrm{Cu}, \mathrm{Zn}$-superoxide dismutase (SOD) to enhance its free radical scavenging role, maintain the balance of glutathione peptide in vivo, clear metal ions, and regulate the antioxidative enzyme system [16]. Histamine dihydrochloride plays an indirect role by blocking the generation of ROM through the $\mathrm{H}_{2}$ receptor. Therefore, it is limited by the quantity and the function of the $\mathrm{H}_{2}$ receptor. Therefore, tiopronin and glutathione perform better than histamine dihydrochloride in clearing the RNM. At the same time, because of its toxic side effects, histamine dihydrochloride is limited in clinical application, while the other two drugs have widely been used in clinical treatment, with few toxic side effects.

Figure 1 showed that the effect of TIP and GSH on clearing RNM and protecting NK cells is dose dependent. It also means that TIP and GSH reverse the inhibition of monocytes on the activity of NK cells. Compared with a single scavenger, two or three scavengers combined can reduce $\mathrm{NO}$ and increase the production of TNF- $\beta$ and IFN- $\gamma$; given that there was no change in NCC $(P>0.05)$, it appears that different combinations of RNM scavengers cannot protect NK cells better. Still, the reason is still not clear.

In conclusion, endogenous and exogenous reactive nitrogen metabolites can act directly on cells, kill NK cells significantly, then reduce NK cells against K562 cells and activate TNF- $\beta$, IFN- $\gamma$, and other cytokines. There are a large number of MO cells in and around malignant tumors, which can cause respiratory burst, especially when activated, thus generating lots of RNMS, inducing NK cells apoptosis and significantly inhibiting NK cells activity. Tiopronin and glutathione are more effective than histamine in clearing RNMS and reversing their inhibitory effect on NK cells in anti-K562 cells with relatively minor toxic side effects and in a dose-dependent fashion. Therefore, they can be used clinically as a better immune adjuvant to improve the efficacy of adoptive immunotherapy for minimal residual tumor/leukemia. However, different combinations of RNM scavengers cannot better protect NK cells.

\section{Conflict of Interests}

The authors report no conflict of interests.

\section{Disclosure}

The authors alone are responsible for the content and writing of the paper.

\section{Acknowledgment}

This research was supported by a college grant receiving financial assistance from the Technology Government Agency of the Fujian province (no. 2007F5043).

\section{References}

[1] K. Hellstrand, M. Brune, C. Dahlgren et al., "Alleviating oxidative stress in cancer immunotherapy: a role for histamine?" Medical Oncology, vol. 17, no. 4, pp. 258-269, 2000.

[2] M. Hansson, S. Hermodsson, M. Brune et al., "Histamine protects T cells and natural killer cells against oxidative stress," Journal of Interferon and Cytokine Research, vol. 19, no. 10, pp. 1135-1144, 1999.

[3] U. H. Mellqvist, M. Hansson, M. Brune, C. Dahlgren, S. Hermodsson, and K. Hellstrand, "Natural killer cell dysfunction and apoptosis induced by chronic myelogenous leukemia cells: role of reactive oxygen species and regulation by histamine," Blood, vol. 96, no. 5, pp. 1961-1968, 2000.

[4] J. X. Pan, L. Lin, J. X. Guo et al., "Effect of reduced glutathione as anti-leukemic immune adjuvant," Zhongguo Shi Yan Xue ye Xue Za Zhi, vol. 14, no. 2, pp. 359-362, 2006.

[5] J. X. Pan and Z. Z. Chen, "How to overcome the obstacles in the adoptive immunotherapy," Chinese Journal of Internal Medicine, vol. 47, no. 2, pp. 91-92, 2008.

[6] K. Sakano, S. Oikawa, K. Hasegawa, and S. Kawanishi, "Hydroxyurea induces site-specific DNA damage via formation of hydrogen peroxide and nitric oxide," Japanese Journal of Cancer Research, vol. 92, no. 11, pp. 1166-1174, 2001.

[7] K. Kono, F. Salazar-Onfray, M. Petersson et al., "Hydrogen peroxide secreted by tumor-derived macrophages downmodulates signal-transducing zeta molecules and inhibits tumor-specific $\mathrm{T}$ cell-and natural killer cell-mediated cytotoxicity," European Journal of Immunology, vol. 26, no. 6, pp. 1308-1313, 1996.

[8] M. Z. Zheng, H. D. Pan, J. X. Pan, and J. X. Guo, "Monocyteinduced NK cell inactivation: role of reactive oxygen and nitrogen metabolites," Immunopharmacology and Immunotoxicology, vol. 33, no. 1, pp. 150-156, 2011.

[9] J. Fang, Z. Tian, and C. Zhang, "Preparation and characteristics of human adherent natural killer cells induced by rhIL-15," Zhonghua Zhong Liu Za Zhi, vol. 23, no. 6, pp. 444-447, 2001.

[10] Y. Wang, S. Chao, and Y. Yao, "Experimental research of monocytic immunological function up-regulated by achyranthes bidentata polysaccharides," Chinese Journal of Hospital Pharmacy, vol. 25, pp. 940-942, 2005.

[11] T. Kiziltepe, T. Hideshima, K. Ishitsuka et al., "JS-K, a GSTactivated nitric oxide generator, induces DNA double-strand breaks, activates DNA damage response pathways, and induces apoptosis in vitro and in vivo in human multiple myeloma cells," Blood, vol. 110, no. 2, pp. 709-718, 2007.

[12] M. P. Nittler, D. Hocking-Murray, C. K. Foo, and A. Sil, "Identification of Histoplasma capsulatum transcripts induced in response to reactive nitrogen species," Molecular Biology of the Cell, vol. 16, no. 10, pp. 4792-4813, 2005.

[13] G. H. Jin, T. Hirano, and M. Murakami, "Combination treatment with IL-2 and anti-IL-2 mAbs reduces tumor metastasis via NK cell activation," International Immunology, vol. 20, no. 6, pp. 783-789, 2008.

[14] M. C. Santos-Silva, M. S. D. Freitas, and J. Assreuy, "Involvement of NF- $\kappa \mathrm{B}$ and glutathione in cytotoxic effects of nitric oxide and taxol on human leukemia cells," Leukemia Research, vol. 30, no. 2, pp. 145-152, 2006.

[15] F. B. Thoren, A. Betten, A. I. Romero, and K. Hellstrand, "Cutting edge: antioxidative properties of myeloid dendritic cells: protection of T cells and NK cells from oxygen radical-induced inactivation and apoptosis," Journal of Immunology, vol. 179, no. 1, pp. 21-25, 2007. 
[16] A. I. Romero, F. B. Thoren, M. Brune, and K. Hellstrand, "NKp46 and NKG2D receptor expression in NK cells with CD56dim and CD56bright phenotype: regulation by histamine and reactive oxygen species," British Journal of Haematology, vol. 132, no. 1, pp. 91-98, 2006. 


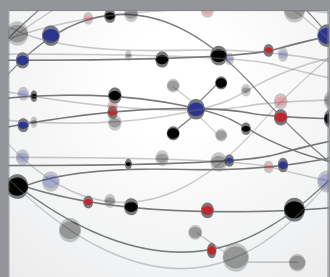

The Scientific World Journal
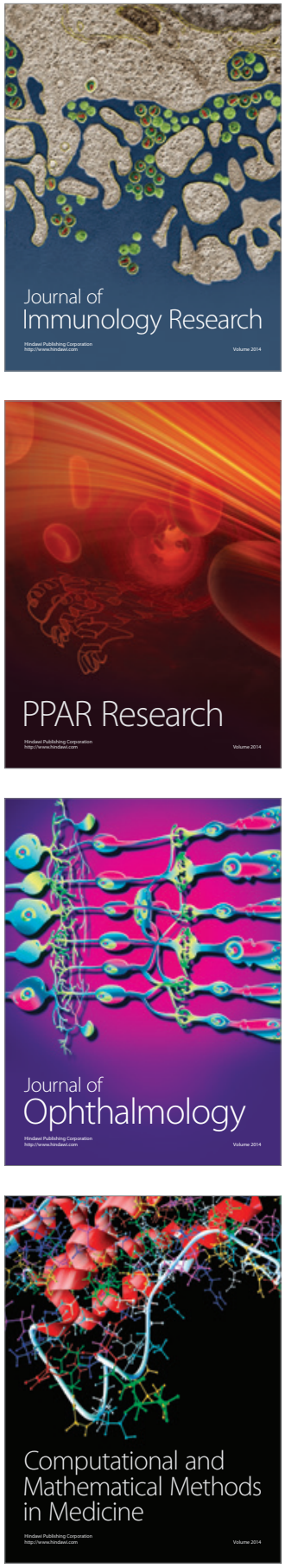

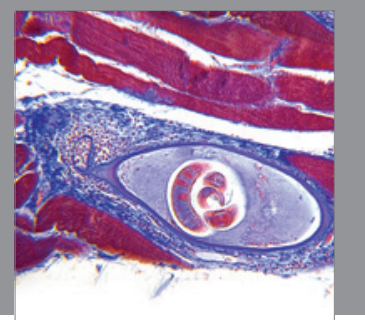

Gastroenterology

Research and Practice
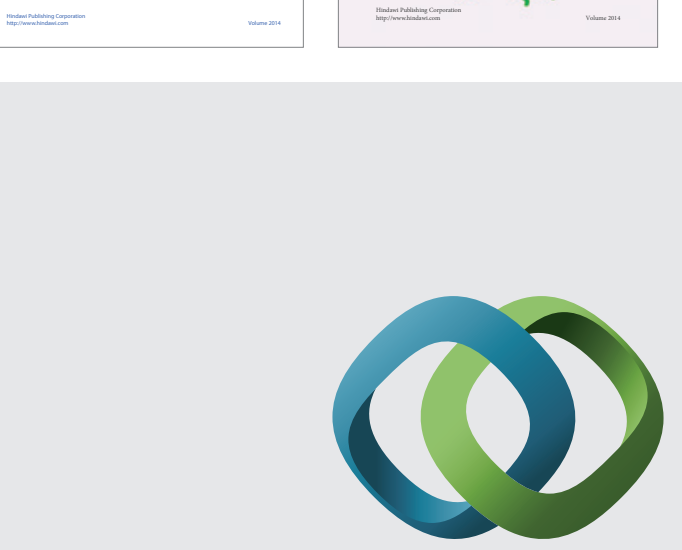

\section{Hindawi}

Submit your manuscripts at

http://www.hindawi.com
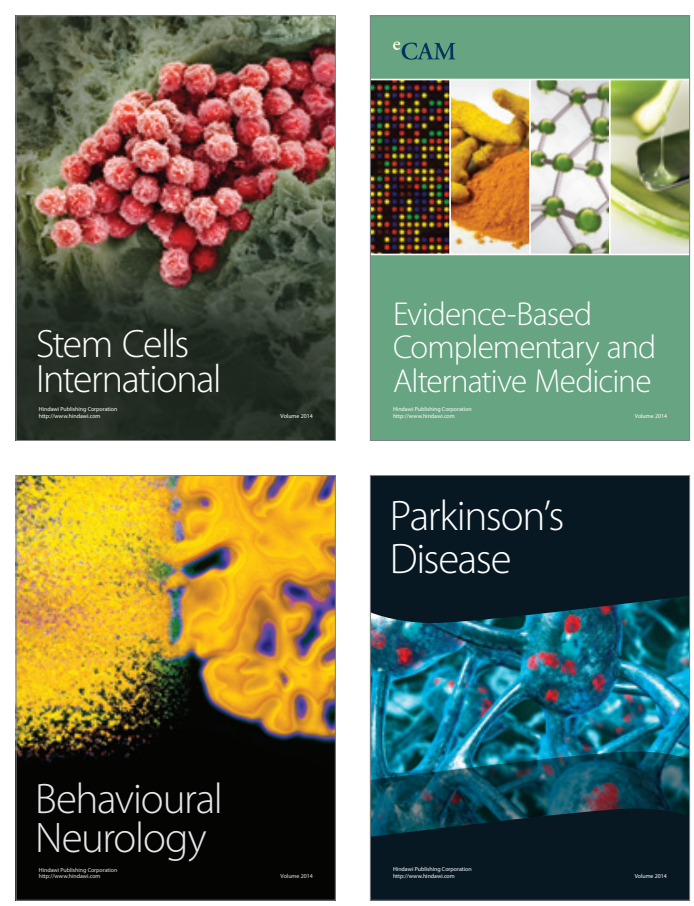

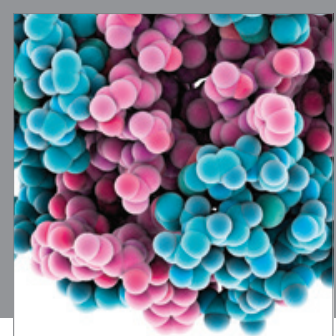

Journal of
Diabetes Research

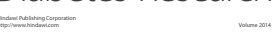

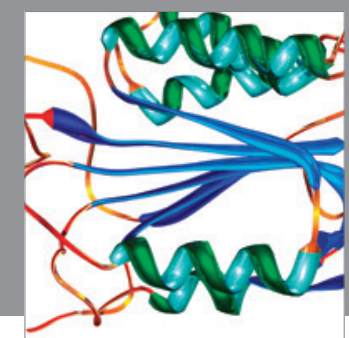

Disease Markers
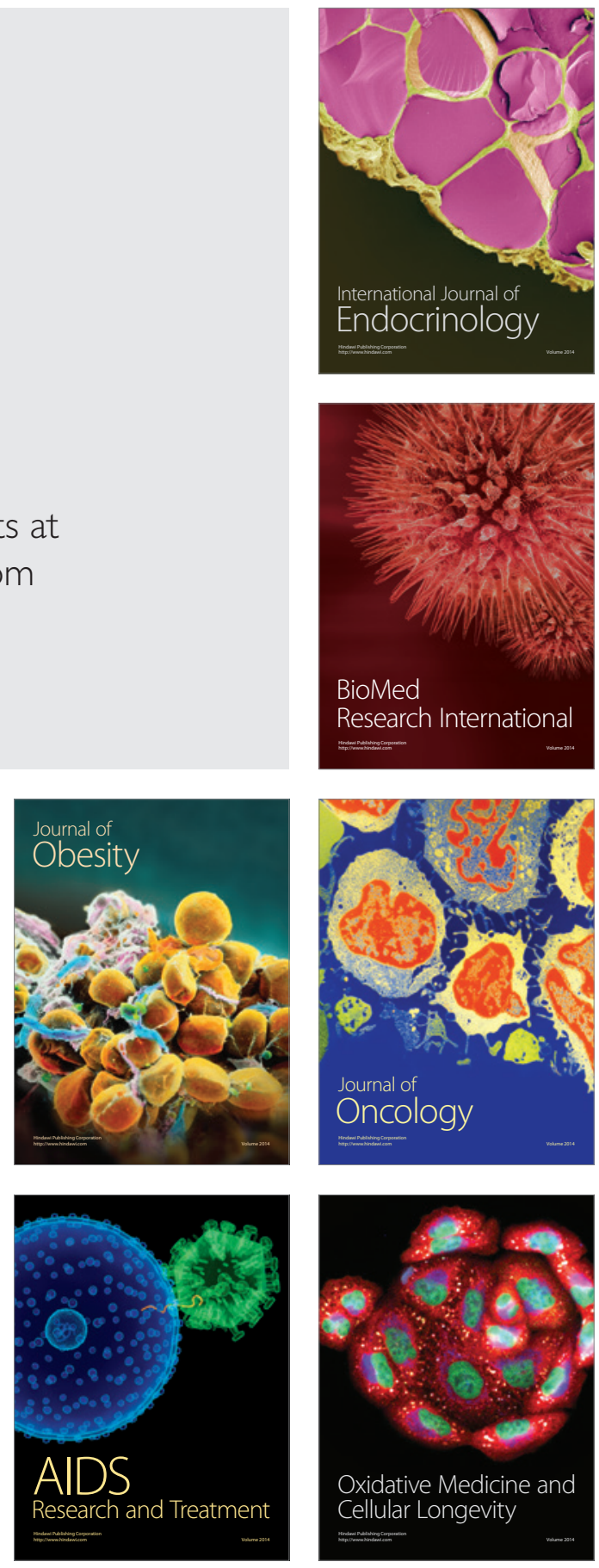